\title{
Antinociceptive Effects of Interleukin-4, -10 , and -13 on the Writhing Response in Mice and Zymosan-Induced Knee Joint Incapacitation in Rats
}

\author{
MARIANA L. VALE, JACIARA B. MARQUES, CAMILA A. MOREIRA, FRANCISCO AÍRTON C. ROCHA, \\ SÉRGIO H. FERREIRA, STEPHEN POOLE, FERNANDO Q. CUNHA, and RONALDO A. RIBEIRO \\ Department of Physiology and Pharmacology, Faculty of Medicine, Federal University of Ceará, Fortaleza, Ceará, Brazil (M.L.V., J.B.M., C.A.M., \\ F.A.C.R., R.A.R.); Department of Pharmacology, Faculty of Medicine of Ribeirão Preto, University of São Paulo, Sao Paolo, Brazil (S.H.F., \\ F.Q.C.); and Endocrinology Section, National Institute for Biological Standards and Control, London, United Kingdom (S.P.) \\ Received May 14, 2002; accepted September 4, 2002
}

\section{ABSTRACT}

The antinociceptive effects of interleukin (IL)-4, -10, and -13 were investigated in two different experimental pain models. Our results showed that pretreatment (30 min) with IL-4 (1-5 ng/animal), IL-10 (0.4-10 ng/animal), or IL-13 (0.4-2.5 ng/animal) inhibited the writhing response induced by the i.p. administration of acetic acid (53-89\%) or zymosan (63-74\%) in mice, and the knee joint incapacitation induced by i.a. injection of zymosan (49-66\%) in rats. Neither of the cytokines affected the pain elicited in mice using the hot-plate test. This analgesic effect of IL-4, -10 , and -13 was not reversed by the combined pretreatment with the opioid receptor antagonist naloxone. IL-4, -10 , or -13 significantly inhibited the release of both tumor
\end{abstract}

necrosis factor (TNF)- $\alpha(60,53$, and $100 \%$, respectively) and IL-1 $\beta$ (80, 100 , and $100 \%$, respectively) by mice peritoneal macrophages obtained after local (i.p.) injection of zymosan. Antisera against IL-4, -10 , and -13 potentiated both the zymosan-induced writhing response and the articular incapacitation. Our results demonstrate that IL-4, -10 , and -13 display analgesic activity that is probably not due to endogenous opioid release. This analgesic effect could be related to a peripheral mechanism, probably via the inhibition of the release of the pro-inflammatory cytokines TNF- $\alpha$ and IL-1 $\beta$ by resident peritoneal macrophages.
Cytokines constitute a link between cellular injury and recognition of nonself and the development of local and systemic signs and symptoms of inflammation (Dinarello et al., 1986; Ferreira et al., 1988; Faccioli et al., 1990). In this context, it was shown in a model of mechanical hyperalgesia that carrageenin-evoked hyperalgesia results from the combined effects of the release of cyclooxygenase products and sympathomimetic amines (Nakamura and Ferreira, 1987). A cascade of cytokine release preceded the generation of these mediators. Carrageenin and lipopolysaccharide caused the release of bradykinin, which stimulated the release of TNF- $\alpha$. TNF- $\alpha$ induced the release of IL- $1 \beta$ and -6 , which stimulated the production of cyclooxygenase products and IL-8, which, in turn, stimulated production of sympathomimetic mediators (Cunha et al., 1991, 1992a; Ferreira et al., 1993). In a differ-

This work was supported by the grants from the following Brazilian Foundations: Fundação de Amparo à Pesquisa no Estado de São Paulo, Conselho Nacional de Desenvolvimento Científico e Tecnológico (Pronex), and Coordenação de Aperfeiçoamento de Pessoal de Nível Superior (Procad).

Article, publication date, and citation information can be found at http://jpet.aspetjournals.org.

DOI: $10.1124 /$ jpet.102.038703 ent model, the writhing test in mice, zymosan, or acetic acid-induced writhing was also mediated by cyclooxygenase products and sympathomimetic amines, the release of which was mediated by TNF- $\alpha$, IL- $1 \beta$, and IL-8 (Duarte et al., 1988; Thomazzi et al., 1997). These cytokines appear to be released by resident peritoneal macrophages and mast cells since the depletion of these cells from the mouse peritoneal cavity abolished the acetic acid- or zymosan-induced writhing response. Furthermore, the increase in the numbers of these cells in the peritoneal cavity enhanced the number of writhing movements induced by both stimuli (Ribeiro et al., 2000).

Within the last decade, cytokines generally regarded as anti-inflammatory have been described that inhibit the production of other cytokines such as IL- $1 \beta,-6,-8$, and TNF- $\alpha$, which are generally regarded as proinflammatory. The class of anti-inflammatory cytokines includes IL-4, -10, -13, and transforming growth factor- $\beta$ (Hart et al., 1989; Fiorentino et al., 1991; Cassatella et al., 1993; Callard et al., 1996).

IL-10 is produced by several cell types, including $\mathrm{Th}_{2}$ lymphocytes, monocytes, macrophages, and mast cells (Fiorentino et al., 1989). IL-10 is believed to play a role in

ABBREVIATIONS: TNF, tumor necrosis factor; IL, interleukin; COX, cyclooxygenase; iNOS, inducible nitric oxide synthase; S, saline; NT, nontreated; Zym, zymosan; Ab IL, antiserum against interleukin. 
inhibiting delayed-type hypersensitivity reactions (Howard and O'Garra, 1992) and in the suppression of macrophage functions such as class II expression (De Waal Malefyt et al., 1991), adhesion (Fiorentino et al., 1991), the synthesis of proinflammatory cytokines, and the expression of COX-2 and iNOS (Bogdan et al., 1991; De Waal Malefyt et al., 1991; Fiorentino et al., 1991; Oswald et al., 1992; Cunha et al., 1992b; Niiro et al., 1995, 1997). Recently, it was shown that IL-10 inhibits the inflammatory mechanical hyperalgesia induced by carrageenin through two mechanisms: inhibition of hyperalgesic cytokine release and blockade of COX-2 induction (Poole et al., 1995).

IL-4 and -13 are produced mainly by $\mathrm{Th}_{2}$ lymphocytes and by mast cells (McKenzie et al., 1993; Burd et al., 1995; De Waal Malefyt et al., 1995) and share a number of biological properties, including the inhibition of proinflammatory cytokine production (Hart et al., 1989; Callard et al., 1996; Muchamuel et al., 1997) and the induction of COX-2 and of iNOS with a consequent reduction in the production of prostaglandins and nitric oxide (Seitz et al., 1994; Niiro et al., 1995; Onoe et al., 1996). Also, IL-4 can suppress the delayedtype hypersensitivity in experimental animals and in humans (Röcken et al., 1996), possibly because of its capacity to induce $\mathrm{Th}_{2}$ cell responses. IL-13 may exert an important role in rheumatoid arthritis since it is present at high levels in synovial fluid and can inhibit the production of IL-1 and TNF by mononuclear cells (Isomaki et al., 1996). Recently, it was shown that IL-4 (probably released by local mast cells) and IL-13 (probably released by local T lymphocytes) inhibited the mechanical hyperalgesia induced by carrageenin, bradykinin, and TNF- $\alpha$ (Cunha et al., 1999; Lorenzetti et al., 2001). This antihyperalgesic effect appeared to be due to inhibition of prostaglandin $\mathrm{E}$ and cytokine production.

Given the demonstrated capacity of IL-4, -10 , and -13 to inhibit mechanical hyperalgesia in rats and the production of proinflammatory hyperalgesic cytokines, the present study extended the investigation of the antinociceptive effect of these molecules, testing their possible antinociceptive effects in the writhing test in mice (Collier et al., 1968), the knee joint incapacitation test in rats (Tonussi and Ferreira, 1992), and the hot-plate test in mice (Eddy and Leimbach, 1953). This last test was used to investigate the possible central effect of these cytokines. The involvement of opioids in the antinociceptive effect of these cytokines was also investigated.

\section{Materials and Methods}

\section{Animals}

Male Swiss mice weighing 25 to $30 \mathrm{~g}$ and male Wistar rats (180$200 \mathrm{~g}$ ) from the animal colony of the Federal University of Ceará were used for nociceptive tests. The animals received water and food ad libitum. The ethical guidelines in the NIH Guide for Care and Use of Laboratory Animals were followed throughout the experiments described.

\section{Nociceptive Tests}

Writhing Test. The writhing test is described in detail elsewhere (Collier et al., 1968). Zymosan or acetic acid were injected into the peritoneal cavities of mice, which were placed in a large glass cylinder, and the intensity of nociception was quantified by counting the total number of writhings occurring between 0 and 30 min after stimulus injection. The writhing response consists of a contraction of the abdominal muscles together with a stretching of the hind limbs. The doses of the nociceptive stimuli were: zymosan $(1 \mathrm{mg} / 0.2 \mathrm{ml} /$ mouse) and acetic acid $(0.1 \mathrm{ml} / 10 \mathrm{~g}$ body weight of a $0.6 \% \mathrm{v} / \mathrm{v}$ solution).

Rat Knee Joint Incapacitation Test. The rat knee joint incapacitation test is described in detail elsewhere (Tonussi and Ferreira, 1992; Rocha et al., 1999). In this test, a computer-assisted device measures the length of time that a specific hind paw fails to touch the surface of a rotating cylinder in a 1-min period (paw elevation time). In normal animals, paw elevation time is approximately 10 to $15 \mathrm{~s}$. In our experiments, incapacitation was studied in animals injected with zymosan ( $1 \mathrm{mg} / \mathrm{animal})$ into the knee joint, and the period for which the hind paw failed to touch the rotating cylinder was interpreted as being proportional to the pain felt by the animal. Paw elevation time was measured before zymosan administration (control time, $\left.T_{0}\right)$ and, thereafter, every hour for $4 \mathrm{~h}\left(T_{1}, T_{2}\right.$, $T_{3}$, and $T_{4}$ ). The results were expressed as $\Delta$ paw elevation time $\left[T_{(1-4)}-T_{0}\right]$.

Hot-Plate Test. Reaction times were measured by the low-temperature $\left(51.5 \pm 2{ }^{\circ} \mathrm{C}\right)$ hot-plate method described by Eddy and Leimbach (1953). Each mouse was subjected to two trials on the hot plate separated by a 30-min interval. The first trial was used for habituation of the animals with the test procedure. The second trial served to obtain the control reaction time (licking of the hind feet or jumping) for each animal. Male Swiss mice were preselected, and animal showing a reaction time greater than $10 \mathrm{~s}$ were discarded. The reaction time for each mouse was determined on the hot-plate surface before and 30,60, and 90 min after drug administration. To avoid injuries, the animals were never left more than $40 \mathrm{~s}$ on the hot plate.

\section{Production of TNF- $\alpha$ and IL-1 $\beta$ by Cells Harvested from Peritoneal Cavities Stimulated with Zymosan}

Saline $(0.2 \mathrm{ml})$ or zymosan $(1 \mathrm{mg} / 0.2 \mathrm{ml})$ was injected i.p. in the mice. After $15 \mathrm{~min}$, the peritoneal cavities were washed with saline $(1 \mathrm{ml} /$ cavity), and the exudates were centrifuged at $300 \mathrm{~g}$ for $10 \mathrm{~min}$. Pelleted cells were resuspended in $500 \mu$ l of RPMI 1640 medium supplemented with $10 \%$ fetal calf serum; cells were then counted, and $5 \times 10^{5}$ cells were plated onto 48 -well plastic tissue culture plates. The concentrations of TNF- $\alpha$ and IL- $1 \beta$ in the supernatants after $12 \mathrm{~h}$ of culture were determined by an enzyme-linked immunosorbent assay, as described previously (Cunha et al., 1999). Briefly, microtiter plates were coated overnight at $4^{\circ} \mathrm{C}$ with an antibody against murine TNF- $\alpha$ or IL- $1 \beta(10 \mu \mathrm{g} / \mathrm{ml})$. After blocking the plates, the samples and standards at various dilutions were added in duplicate and incubated at $4^{\circ} \mathrm{C}$ for $24 \mathrm{~h}$. The plates were washed three times with buffer, and a second biotinylated polyclonal antibody against TNF- $\alpha$ or IL- $1 \beta$ (diluted 1/1000; $100 \mu \mathrm{l} /$ well) was added. After a further incubation at room temperature for $1 \mathrm{~h}$, the plates were washed, and $100 \mu \mathrm{l}$ of avidin-horseradish peroxidase, diluted 1:5000, was added. $O$-Phenylenediamine color reagent $(100 \mu \mathrm{l})$ was added $15 \mathrm{~min}$ later, and the plates were incubated in the dark at $37^{\circ} \mathrm{C}$ for 15 to $20 \mathrm{~min}$. The enzyme reaction was stopped with $\mathrm{H}_{2} \mathrm{SO}_{4}$, and the absorbency at $490 \mathrm{nM}$ was measured. Results are reported as means \pm S.E.M. of three animals.

\section{Experimental Protocols}

Effect of Pretreatment with IL-4, -10, and -13 on the Writhing Response Induced by Acetic Acid or Zymosan. Mice were treated i.p. with murine IL-4 (1-5 ng/cavity), IL-10 (0.4-10 ng/ cavity), or human IL-13 (0.4-2.5 ng/cavity), and after $30 \mathrm{~min}$, zymosan $(1 \mathrm{mg} / 0.2 \mathrm{ml} / \mathrm{mouse})$ or $0.1 \mathrm{ml} / 10 \mathrm{~g}$ body weight of acetic acid solution at concentration of $0.6 \%(\mathrm{v} / \mathrm{v})$ was injected i.p. The number of writhes was counted as described above.

Effect of Pretreatment with IL-4, -10, and -13 on the Rat Knee Joint Incapacitation Induced by Zymosan. Rats were treated i.p. with human IL-4 (1-5 ng/cavity), IL-10 (2-10 ng/cavity), 
or IL-13 (1-2.5 ng/cavity), and after $30 \mathrm{~min}$, zymosan (1 mg/joint) was injected i.a. in a volume of $50 \mu \mathrm{l}$. Incapacitation was measured as described above.

Effect of IL-4, -10, and -13 in the Hot-Plate Test. Immediately after determination of control reaction time (see above), groups of six mice were treated i.p. with saline, IL-4 (5 ng/cavity), IL-10 (10 ng/cavity), IL-13 (2.5 ng/cavity), morphine ( $5 \mathrm{mg} / \mathrm{kg})$, or indomethacin $(2 \mathrm{mg} / \mathrm{kg})$ in a volume of $0.2 \mathrm{ml}$. The reaction time was measured 30,60 , and 90 min after the treatment.

Effect of Pretreatment with Naloxone upon the Antinociceptive Activity of IL-4, -10, and -13 in Acetic Acid-Induced Writhings in Mice. Mice were pretreated s.c. with saline or naloxone $(2 \mathrm{mg} / \mathrm{kg})$. Fifteen minutes later they were injected i.p. with saline, murine IL-4 (5 ng/cavity), murine IL-10 (10 ng/cavity), human IL-13 (2.5 ng/cavity), or morphine ( $5 \mathrm{mg} / \mathrm{kg})$. Thirty minutes after, acetic acid $(0.1 \mathrm{ml} / 10 \mathrm{~g}$ body weight of a $0.6 \% \mathrm{v} / \mathrm{v}$ solution) was injected i.p., and the number of writhings was determined as described above.

Effect of IL-4, -10, and -13 Pretreatment upon TNF- $\alpha$ and IL-1 $\beta$ Production by Peritoneal Cells Harvested from Cavities Stimulated with Zymosan. Mice were pretreated i.p. with murine IL-4 (5 ng/cavity), murine IL-10 (10 ng/cavity), or human IL-13 (2.5 ng/cavity) $30 \mathrm{~min}$ before the i.p. administration of zymosan $(1 \mathrm{mg} /$ cavity). The control group received only saline (S) $(0.2 \mathrm{ml})$ and a nontreated (NT) group received saline before the zymosan. After 15 min, total resident peritoneal cells were harvested with RPMI 1640 culture medium, plated $\left(5 \times 10^{5}\right.$ cells/well) and incubated in a $\mathrm{CO}_{2}$ incubator. TNF- $\alpha$ and IL- $1 \beta$ levels were measured in the supernatants after $12 \mathrm{~h}$ of culture.

Effect of Antisera against Interleukin-4, -10, and -13 upon the Nociceptive Activity of Zymosan in the Writhing Test. Fifty microliters of antiserum against murine interleukin-4, -10, or -13 , or of a control (preimmune) serum were diluted in $250 \mu \mathrm{l}$ of saline and then injected into the peritoneal cavities of mice; $15 \mathrm{~min}$ later, animals received an i.p. injection of zymosan $(500 \mu \mathrm{g} / 0.2 \mathrm{ml} /$ mouse). The writhings were counted as described above.

Effect of Antisera against Interleukin-4, -10, and 13 upon the Nociceptive Activity of Zymosan in the Rat Knee Joint Incapacitation Test. Fifty microliters of antiserum against rat interleukin-4, -10 , or -13 , or of a control (preimmune) serum were injected into the rat right knee joint cavity; 15 min later, zymosan (500 $\mu \mathrm{g} / 25 \mu \mathrm{l} /$ cavity) was injected into the same articular cavity. Articular incapacitation was measured as described above.

\section{Compounds}

The following materials were obtained from the sources indicated: zymosan A (Sigma-Aldrich, St. Louis, MO), glacial acetic acid (Merck, São Paulo, Brazil), indomethacin (Merck, Sharp and DohmeMSD, São Paulo, Brazil), morphine (Cristalia-Brazil, São Paulo, Brazil), naloxone (Rhodia Farma, São Paulo, Brazil). Recombinant human and murine IL-4, human and murine IL-10, and human IL-13 [National Institute for Biological Standards and Control (NIBSC) preparations coded: 88/656, 92/516, and 94/662]. The specific activities of these materials are: IL-4, $1000 \mathrm{IU} 100 \mathrm{ng}^{-1} \mathrm{am}$ poule $^{-1}$; IL-10, 5000 IU $1 \mu \mathrm{g}^{-1}$ ampoule $^{-1}$; and IL-13, $1000 \mathrm{IU} 1$ $\mathrm{mg}^{-1}$ ampoule ${ }^{-1}$. Zymosan, morphine, naloxone, and the cytokines used were all diluted in a $0.9 \% \mathrm{NaCl}$ solution. Indomethacin was diluted in a $5 \% \mathrm{NaHCO}_{3}$ solution, and $\mathrm{pH}$ was adjusted to 8.0 using $0.1 \mathrm{~N} \mathrm{HCl}$. Glacial acetic acid was diluted in deionized water. Sheep anti-murine or anti-rat IL-4, -10, and -13 sera, and preimmune serum were NIBSC preparations.

\section{Data Analysis}

Results are presented as means \pm S.E.M. of measurements made on at least six animals in each group. Differences between responses were evaluated by analysis of variance followed by Tukey's test. Statistical differences were considered to be significant at $p<0.05$.

\section{Results}

Effect of Pretreatment with IL-4, -10, and -13 on the Writhing Response to Acetic Acid or Zymosan. The intraperitoneal injection in mice of $0.1 \mathrm{ml} / 10 \mathrm{~g}$ body weight of a $0.6 \%(\mathrm{v} / \mathrm{v})$ solution of acetic acid or zymosan (1 mg/mouse) induced a writhing response between 0 and $30 \mathrm{~min}$ later. IL-4 (1-5 ng/cavity), IL-10 (0.4-10 ng/cavity), or IL-13 (0.4-2.5 $\mathrm{ng} /$ cavity) injected i.p. $30 \mathrm{~min}$ before either of the stimuli significantly inhibited the nociceptive response $(p<0.001)$ with 59,53 , and $89 \%$ of inhibition on average for the different doses when the stimulus was acetic acid (Fig. 1A) and 63, 74, and $62 \%$ on average for the different doses when the stimulus was zymosan (Zym) (Fig. 1B), for IL-4, -10, and -13, respectively.

Effect of Pretreatment with IL-4, -10, and -13 on the Rat Knee Joint Incapacitation Induced by Zymosan. The intra-articular injection of zymosan (1 mg/cavity) induced articular incapacitation, which was maximal in the 3rd and 4 th $\mathrm{h}$ after stimulus injection. IL-4 at a dose of $5 \mathrm{ng} /$ cavity, but not at a dose of $1 \mathrm{ng} /$ cavity, significantly inhibited the zymosan-evoked nociception in the 3rd h by $49 \%$ ( $p<$ 0.01; Fig. 2A). IL-10 (2 and $10 \mathrm{ng} /$ cavity) blocked the nociceptive effect in the $3 \mathrm{rd}$ and 4 th $\mathrm{h}$ by 65 and $66 \%(p<0.01)$, respectively (Fig. 2B). IL-13 (1 and $2.5 \mathrm{ng} /$ cavity) inhibited the nociceptive response in the $3 \mathrm{rd} h$ by $57 \%(p<0.05)$, but only the dose of $1 \mathrm{ng} /$ cavity was effective in the $4 \mathrm{th} \mathrm{h}$ of
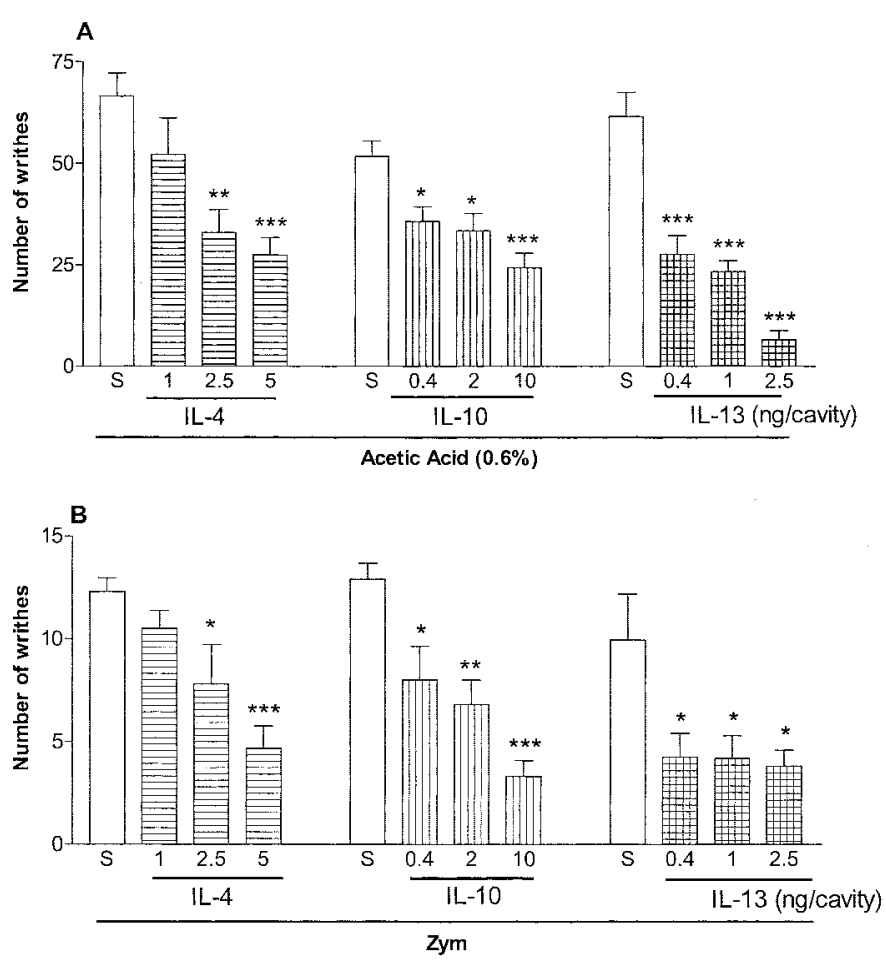

Fig. 1. Effects of the systemic administration of IL-4, -10, and -13 on the writhing response to acetic acid or zymosan in mice. The number of writhes was determined between 0 and 30 min after i.p. injection of 0.1 $\mathrm{ml} / 10 \mathrm{~g}$ body weight of acetic acid at a concentration of $0.6 \%(\mathrm{v} / \mathrm{v})(\mathrm{A})$ or Zym (1 mg/mouse) (B). Animals receiving saline i.p. injection before stimulus were designated NT animals (control). IL-4 (1-5 ng/cavity), IL-10 (0.4-10 ng/cavity), and IL-13 (0.4-2.5 ng/cavity) were given $30 \mathrm{~min}$ before acetic acid or zymosan. Results are expressed as means \pm S.E.M. for the groups of six mice. Asterisks indicate statistically significant differences compared with respective controls ( $\star, p<0.05 ; \star \star, p<0.01$; $\star \star \star, p<0.001)$. 


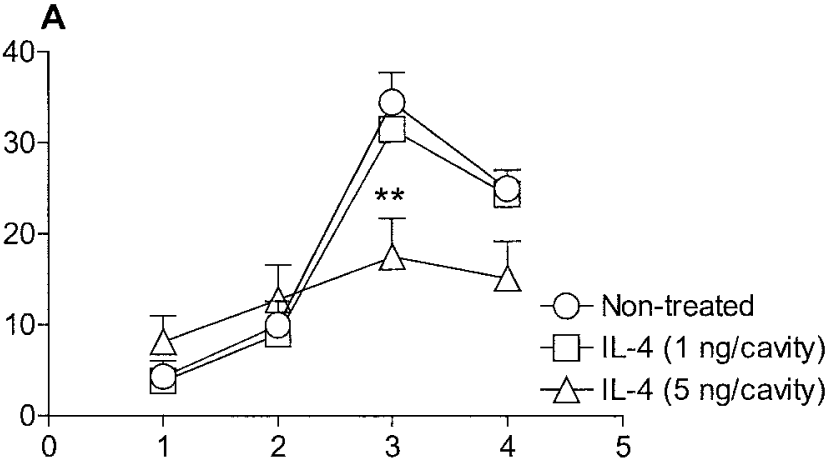

B
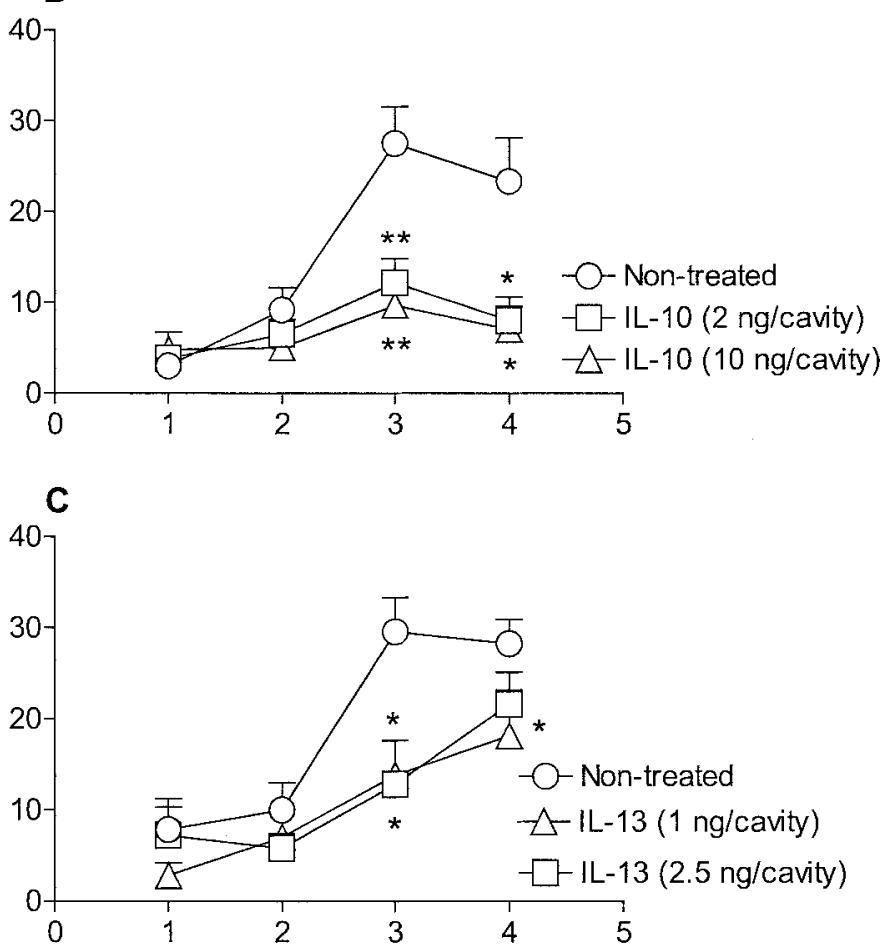

Fig. 2. Effects of systemic administration of IL-4, -10, and -13 on zymosan-evoked articular incapacitation in rats. IL-4 (1 and $5 \mathrm{ng} /$ cavity) (A), IL-10 (2 and $10 \mathrm{ng} /$ cavity) (B), or IL-13 (1 and $2.5 \mathrm{ng} /$ cavity) (C) were injected i.p., and $30 \mathrm{~min}$ later, zymosan $(1 \mathrm{mg} /$ cavity; $50 \mu \mathrm{l})$ was injected intra-articularly into the right knee joint. Paw elevation time was measured before and after zymosan administration over a 60 -min period until the 4 th $\mathrm{h}$. Animals receiving saline i.p. injections before stimulus were designated nontreated animals. Results are expressed as means \pm S.E.M. of the $\Delta$ paw elevation time(s) for the groups of six rats. Asterisks indicate statistically significant differences between groups and respective controls $(\star, p<0.05 ; \star \star, p<0.01)$.

incapacitation $(35 \% ; p<0.05)$ when compared with the control group (Fig. 2C).

Effect of IL-4, -10, and -13 on the Hot-plate Response. IL-4 (5 ng/cavity), IL-10 (10 ng/cavity), IL-13 (2.5 ng/cavity), or indomethacin $(2 \mathrm{mg} / \mathrm{kg})$ administrated i.p. to mice did not alter the reaction time during $90 \mathrm{~min}$ of observation. In contrast, morphine ( $5 \mathrm{mg} / \mathrm{kg}$, i.p.), used as a positive control, caused a significant elevation (up to $660 \%$ ) of the reaction time of the animals during this period (Fig. 3).

Effect of Pretreatment with Naloxone Upon the Antinociceptive Activity of IL-4, -10, and -13 in Acetic Acid-Induced Writhing in Mice. Subcutaneous injection of naloxone $15 \mathrm{~min}$ before IL-4 (5 ng/cavity), IL-10 (10 ng/

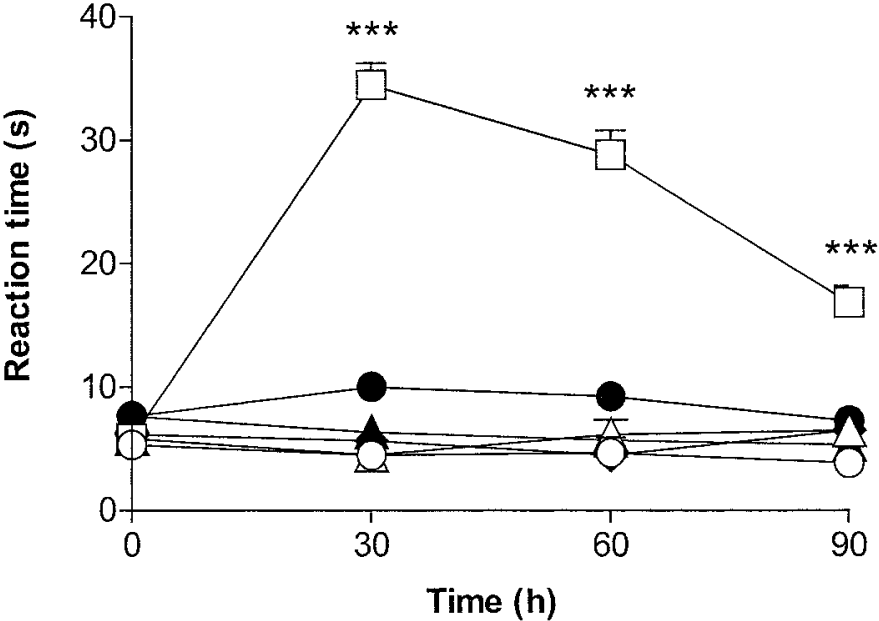

Fig. 3. Effects of IL-4, IL-10, IL-13, indomethacin, or morphine on the course of the reaction times to a thermal stimulus (hot-plate) in mice Mice were pretreated i.p. with saline $(\bigcirc$; control), morphine $(\square ; 5 \mathrm{mg} / \mathrm{kg})$, indomethacin ( $\triangle ; 2 \mathrm{mg} / \mathrm{kg})$, IL-4 ( ; $5 \mathrm{ng} /$ cavity), IL-10 (•; $10 \mathrm{ng} /$ cavity) or IL-13 $(\boldsymbol{\Lambda} ; 2.5 \mathrm{ng} /$ cavity $)$. Reaction times were measured before injection of the above substances (control time) and 30,60, and 90 min afterward. Results are expressed as means \pm S.E.M. for the groups of six mice. Asterisks indicate statistically significant differences between treated groups and control (nontreated mice; $\star \star \star, p<0.001$ ).

cavity), or IL-13 (2.5 ng/cavity) did not affect the antinociceptive activity of these cytokines in the writhing response to acetic acid $(0.1 \mathrm{ml} / 10 \mathrm{~g}$ body weight of a $0.6 \% \mathrm{v} / \mathrm{v}$ solution $)$ in mice. This dose of naloxone, however, blocked the analgesic effect of morphine (5 mg/kg, i.p.; Fig. 4). In the same manner, naloxone had no effect upon antinociceptive activity of the cytokines on articular incapacitation induced by zymosan (data not shown).

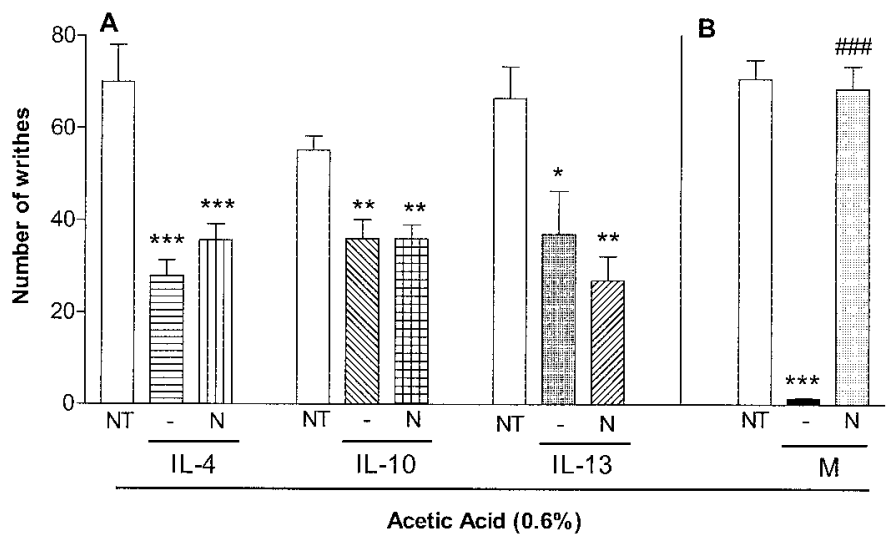

Fig. 4. Effects of naloxone upon the antinociception produced by IL-4, -10 -13 , and morphine in the acetic acid-induced writhing test. IL-4 (5 ng/ cavity), IL-10 (10 ng/cavity), or IL-13 (2.5 ng/cavity) were given i.p. in mice pretreated $15 \mathrm{~min}$ before either saline $(-;$ s.c. $)$ or naloxone $(\mathrm{N} ; 2$ $\mathrm{mg} / \mathrm{kg}$ s.c.). Fifteen minutes after the injection of the cytokines, animals received an i.p. injection of $0.1 \mathrm{ml} / 10 \mathrm{~g}$ body weight of acetic acid at a concentration of $0.6 \%(\mathrm{v} / \mathrm{v})$, and the number of writhes in the following 30 min was determined. A control experiment to ascertain naloxone efficacy was performed injecting naloxone ( $\mathrm{N} ; 2 \mathrm{mg} / \mathrm{kg}$ s.c.) before morphine (M; 5 $\mathrm{mg} / \mathrm{kg}$ ) shown in B. Animals receiving only saline i.p. injection before acetic acid were designated NT animals (control). Results are expressed as means \pm S.E.M. for the groups of six mice. Asterisks indicate compared with the respective control $(\star, p<0.05$; $\star \star, p<0.01 ; \star \star \star, p<$ 0.001 ); \#, indicates statistically significant differences between morphine treated group and the group receiving naloxone in association with morphine in the control experiment illustrated in B (\#\#\#, $p<0.001$ ). 
Effect of IL-4, -10, and IL-13 upon TNF- $\alpha$ and IL-1 $\beta$ Production by Peritoneal Cells Harvested from Cavities Stimulated with Zymosan. The peritoneal cells harvested from cavities stimulated 15 min before with zymosan ( $1 \mathrm{mg} / \mathrm{animal}$ ) released significant amounts of TNF- $\alpha$ and IL- $1 \beta$ into the supernatant after incubation for $12 \mathrm{~h}$ in vitro compared with the cells harvested from cavities injected only with saline. IL-4 (5 ng/cavity), IL-10 (10 ng/cavity), or IL-13 (2.5 ng/cavity) pretreatment caused a significant decrease of both TNF- $\alpha(60 \%, p<0.05 ; 53 \%, p<0.05 ; 100 \%, p<0.001$, respectively) and IL-1 $\beta(80 \%, p<0.05 ; 100 \%, p<0.001$; $100 \%, p<0.001$, respectively) release when compared with the zymosan-only group (Fig. 5).

Potentiation by Antisera Against Interleukin-4, -10, or -13 of the Nociceptive Response to Zymosan in the Writhing Test in Mice. Antisera against IL-4, -10, and -13 (50 $\mu$ l; i.p.), but not a preimmune (control) serum (50 $\mu$ l; i.p.), injected $15 \mathrm{~min}$ before zymosan $(500 \mu \mathrm{g} / 0.2 \mathrm{ml} /$ mouse; i.p.) potentiated the zymosan-induced nociceptive writhing response: Ab IL-4 = 63\% $(p<0.05)$; Ab IL-10 $=95 \%(p<0.01)$, and $\mathrm{Ab}$ IL-13 $=95 \%(p<0.01$; Fig. $6 \mathrm{~A})$.

Potentiation by Antisera Against Interleukin-4, -10, or -13 of the Nociceptive Response to Zymosan in the Rat Knee Joint Incapacitation Test. Antisera against IL-4, -10, or -13 (50 $\mu$ l i.a.), but not a preimmune (control) serum (50 $\mu$ l i.a.), injected 15 min before zymosan ( $500 \mu \mathrm{g} / 25$ $\mu \mathrm{l} /$ cavity; i.a.) potentiated the zymosan-induced nociception in the knee joint when compared with nontreated animals: Ab IL-4 $=181 \%(p<0.05)$, Ab IL-10 $=222 \%(p<0.05)$, and Ab IL-13 = 287\% ( $p<0.001$; Fig. 6B).

\section{Discussion}

IL-4, -10, and -13 are classified as anti-inflammatory cytokines. The principal anti-inflammatory activities of these molecules are a consequence of their capacity to inhibit the production of proinflammatory cytokines such as IL- $1 \beta,-6$, $-12,-18, \mathrm{TNF}-\alpha$, and chemokines (Hart et al., 1989; De Waal Malefyt et al., 1991; Fiorentino et al., 1991; Cassatella et al.,

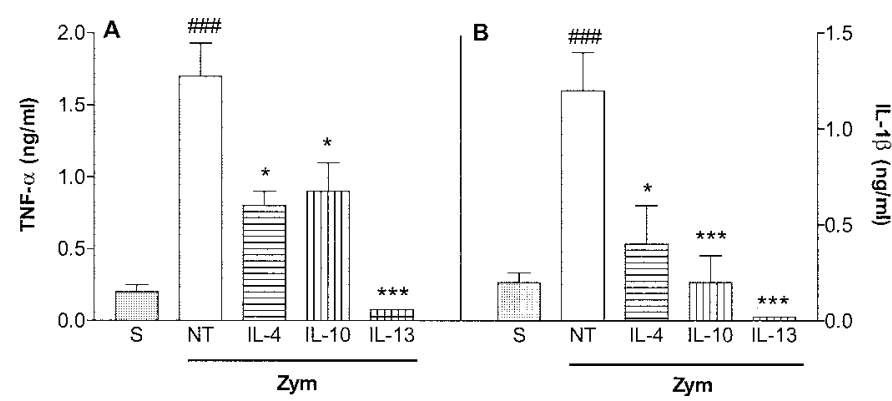

Fig. 5. Effects of IL- $4,-10$, and -13 pretreatment on TNF- $\alpha$ and IL- $1 \beta$ production by cells harvested from peritoneal cavities injected with zymosan. The animals were injected with saline (S; $0.2 \mathrm{ml} /$ cavity) or Zym (1 $\mathrm{mg} /$ cavity), and $15 \mathrm{~min}$ later, the peritoneal cells were harvested and incubated in vitro for $12 \mathrm{~h}$. The concentration of TNF- $\alpha$ (A) and IL-1 $\beta$ (B) in the supernatants was then determined by enzyme-linked immunosorbent assay. IL-4 (5 ng/cavity), IL-10 (10 ng/cavity), or IL-13 (2.5 ng/cavity) was given i.p. 30 min before zymosan injection. "S" represents a group that received only saline i.p. and "NT" represents nontreated mice that received saline before the zymosan. Results are reported as means \pm S.E.M. for the four wells ( $1 \mathrm{animal} / \mathrm{well})$ and are representative of two different experiments. Asterisks indicate statistically significant differences between groups and respective controls $(\star, p<0.05$; $\star \star \star, p<$ $0.001)$; \#, symbol indicate differences between saline and nontreated group (\#\#\#, $p<0.001$ ).

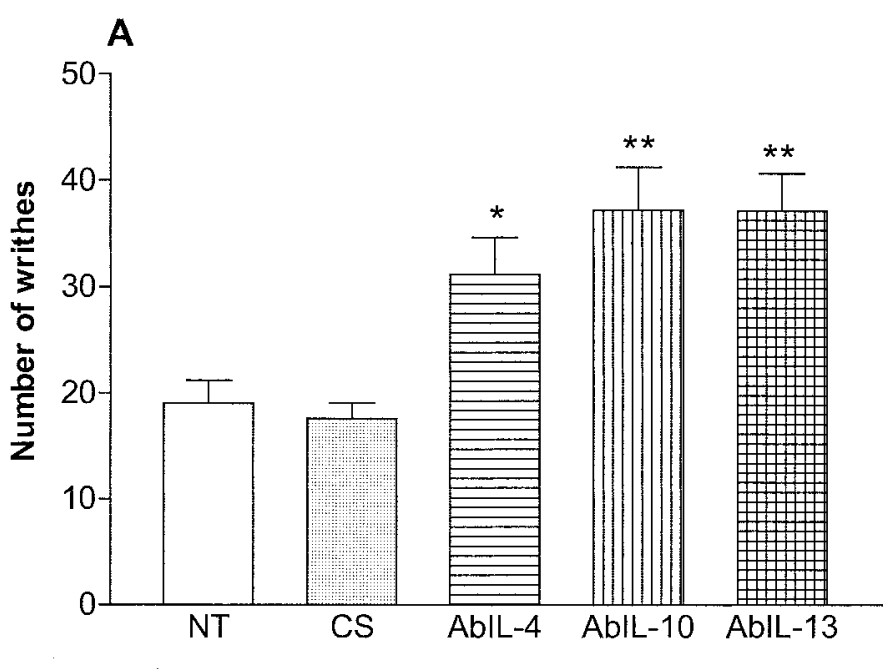

Zym

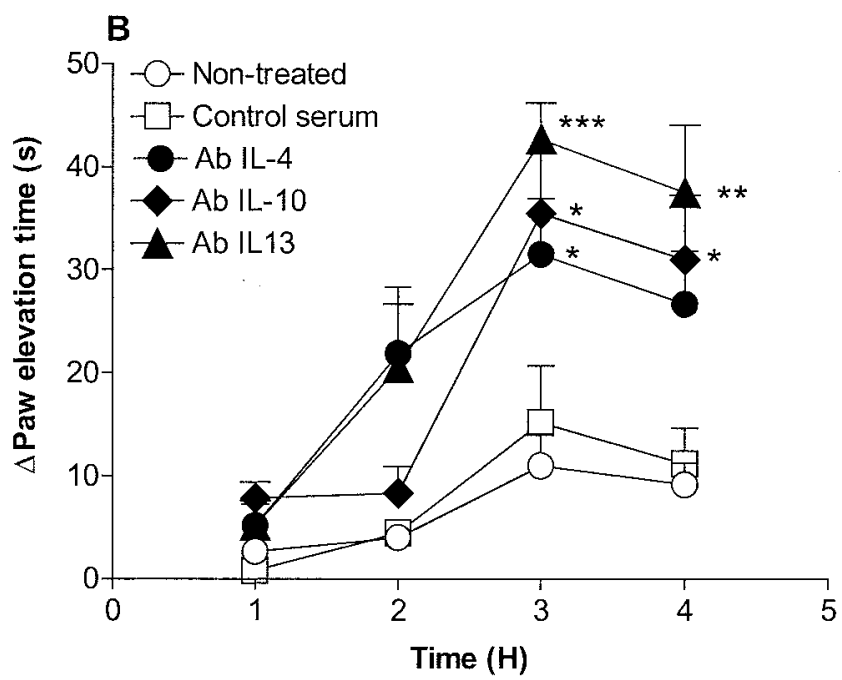

Fig. 6. Effects of systemic administration of antisera against IL-4, -10, and -13 on the writhing response to zymosan in mice (A) and on zymosanevoked articular incapacitation in rats (B). A, the number of writhes between 0 and $30 \mathrm{~min}$ after i.p. injection of Zym ( $500 \mu \mathrm{g} /$ mouse $)$ was determined. B, paw elevation time (incapacitation) was measured before and $1,2,3$, and $4 \mathrm{~h}$ after intra-articular administration of zymosan (see Materials and Methods). In both panels, control serum (CS; $50 \mu \mathrm{l})$ and antiserum against IL-4 (Ab IL-4; $50 \mu \mathrm{l}$ ), IL-10 (Ab IL-10; $50 \mu \mathrm{l}$ ), or IL-13 (Ab IL-13; $50 \mu \mathrm{l}$ ) were given 15 min before zymosan administration. The NT received only zymosan. Results are expressed as means \pm S.E.M. of the $\Delta$ paw elevation time(s) for the groups of six rats. Asterisks indicate statistically significant differences compared with control group $(\star, p<$ $0.05 ; \star \star, p<0.01 ; \star \star \star, p<0.001)$.

1993; Isomaki et al., 1996; Muchamuel et al., 1997). Moreover, they also inhibit the induction of the enzymes COX-2 and iNOS, which are involved in the production of prostaglandins and NO, respectively (Cunha et al., 1992b; Niiro et al., 1995; Onoe et al., 1996; Niiro et al., 1997). Using a model of inflammatory mechanical hyperalgesia (a rat paw pressure test), it was shown that IL-4, -10, and -13 have antihyperalgesic effects. These antihyperalgesic effects are due to inhibition of the release of hyperalgesic cytokines and also eicosanoids, although we cannot exclude the possibility of the involvement of other mediators (Poole et al., 1995; Cunha et al., 1999; Lorenzetti et al., 2001).

In the present study, we demonstrated that IL-4, -10, and -13 inhibited the writhing response in mice after the intra- 
peritoneal injection of zymosan or acetic acid, and the kneejoint incapacitation induced by the intra-articular injection of zymosan into the rat knee joints. The mediators involved in the genesis of the nociception observed in the writhing test are the eicosanoids and sympathomimetic amines, the release of which is preceded by the release of the nociceptive cytokines TNF- $\alpha$, IL-1 $\beta$, and IL-8 (Duarte et al., 1988; Thomazzi et al., 1997; Ribeiro et al., 2000). The rat knee-joint incapacitation test was designed for the study of articular incapacitation, defined as the inability of a rat subjected to an experimentally induced arthritis to deambulate normally (Tonussi and Ferreira, 1992). In this test, articular incapacitation is assumed to be due to altered nociception following injection of an inflammatory substance, such as carrageenin or zymosan, into the joints (Tonussi and Ferreira, 1992; Rocha et al., 1999). After zymosan injection, the animals display a progressive articular incapacitation that begins in the $2 \mathrm{nd} \mathrm{h}$ and is maximal between the 3rd and 4 th $\mathrm{h}$ of arthritis (Rocha et al., 1999). Eicosanoids and TNF- $\alpha$ are involved in the genesis of the knee joint incapacitation (Tonussi and Ferreira, 1992; Rocha et al., 1999).

There is evidence in the literature showing that several cytokines, including peripherally released IL-10, are able to cross the blood-brain barrier and act on the central nervous system (Di Santo et al., 1997). To investigate a possible central component of IL-4, -10, and IL-13 antinociceptive effects, the hot-plate test was used. Although morphine, used as a control, caused a significant elevation in the test reaction time, the cytokines had no effect. There is evidence in the literature, however, showing that IL-10 injected peripherally is able to inhibit pain behavior following intraspinal injection of quisqualic acid (Plunkett et al., 2001). The use of different experimental models could explain these apparently conflicting results. Although we used the hot-plate test in this study, other authors have used a model in which there is a marked expression of inflammatory cytokines within the central nervous system (Di Santo et al., 1997; Plunkett et al., 2001). In our study, IL-4, -10, and -13 seem to exert their antinociceptive effect through a peripheral mechanism via inhibition of the release of proinflammatory cytokines, although we cannot exclude the interference of a centrally derived mechanism.

It is known that some cytokines can stimulate endogenous opioid release (Czlonkowski et al., 1993). In this context, we found that IL-4, -10, and -13 differed from morphine in that their antinociceptive actions were not reversed by pretreatment with naloxone (an opioid antagonist), suggesting that endogenous opioids probably are not involved in the analgesic effect of these cytokines.

Recently, we have demonstrated that the writhing response induced by zymosan and acetic acid in mice is dependent on the presence of resident peritoneal macrophages and mast cells and the consequent release of IL- $1 \beta$ and TNF- $\alpha$ by these cells. It was shown that reduction of the peritoneal macrophage or mast cell population significantly inhibited the zymosan- or acetic acid-induced writhing response. On the other hand, increasing the peritoneal macrophage population caused an increase in the number of writhings induced by both stimuli (Ribeiro et al., 2000). It was also found that the mediators involved in the abdominal writhing test are multiple and include sympathomimetic amines and eicosanoids. Previous data from our group have shown that the release of these pronociceptive substances is preceded by the release of the proinflammatory cytokines IL- 1 , TNF, and IL-8 in zymosan and acetic acid induced writhes (Duarte et al., 1988; Thomazzi et al., 1997; Ribeiro et al., 2000). In the present study, we demonstrated that intraperitoneal administration of IL- $4,-10$, or -13 inhibited the release of IL- $1 \beta$ and TNF- $\alpha$ by macrophages harvested from the peritoneal cavity after zymosan injection. These molecules also inhibit the production of eicosanoids by macrophages harvested from peritoneal cavities of mice and stimulated by cytokines (Poole et al., 1995; Cunha et al., 1999; Lorenzetti et al., 2001). These results suggest that the antinociceptive effects of the cytokines used in this study are due to inhibition both of the release by resident peritoneal cells of cytokines that mediate nociception, such as TNF- $\alpha$ and IL- $1 \beta$, and also the expression of COX-2 induced by these cytokines.

The potentiation of the zymosan-induced writhing response and knee joint incapacitation by specific antibodies to IL-4, -10, and IL-13 suggests that endogenous release of these cytokines has a role in limiting the development of the nociceptive response at least during inflammatory pain reactions. In previous studies, we have demonstrated that antibodies against IL-4, -10 , and -13 also potentiated the mechanical hyperalgesia induced by intraplantar injection of carrageenin and that the potentiation was due to inhibition of the release of inflammatory cytokines (Poole et al., 1995; Cunha et al., 1999; Lorenzetti et al., 2001).

In summary, our data provide evidence that IL- $4,-10$, and -13 display antinociceptive activity that is at least partially due to the inhibition of the release of the proinflammatory cytokines IL-1 and TNF. Additionally, these analgesic cytokines may exert an endogenous down-regulating effect in the release of the eicosanoids. The fact that these cytokines share a similar analgesic effect suggest that a common pathogenic pathway downstream from the receptor coupling of these cytokines may be operating. Such a mechanism could be an interesting target to develop new analgesic therapeutic options.

\section{Acknowledgments}

We are grateful for the technical assistance of Sérgio Roberto Rosa and Giuliana Bertozzi Francisco.

\section{References}

Bogdan C, Vodovotz Y, and Nathan C (1991) Macrophage deactivation by interleukin-10. J Exp Med 174:1549-1555.

Burd PR, Thompson WC, Max EE, and Mills FC (1995) Activated mast cells produce interleukin-13. J Exp Med 181:1373-1380.

Callard RE, Mattheus DJ, and Hibbert L (1996) IL-4 and IL-13 receptors: are they one and the same? Immunol Today 17:108-110.

Cassatella MA, Meda L, Bonora S, Ceska M, and Constantin G (1993) Interleukin-10 (IL-10) inhibits the release of proinflammatory cytokines from human polymor phonuclear leukocytes. Evidence for an autocrine role of tumor necrosis factor and IL- $1 \beta$ in mediating the production of IL- 8 triggered by lipopolysaccharide. $J$ Exp Med 178:2207-2211.

Collier HOJ, Dinneen LC, Chistine A, Johnson A, and Schneider C (1968) The abdominal constriction response and its suppression by analgesic drugs in the mouse. Br J Pharmacol Chemother 32:295-310.

Cunha FQ, Lorenzetti BB, Poole S, and Ferreira SH (1991) Interleukin-8 as a mediator of sympathetic pain. Br J Pharmacol 104: 765-767.

Cunha FQ, Moncada S, and Liew FY (1992b) Interleukin-10 (IL-10) inhibits the induction of nitric oxide synthase by interferon- $\gamma$ in murine macrophages. Biochem Biophys Res Commun 182:1155-1159.

Cunha FQ, Poole S, Lorenzetti BB, and Ferreira SH (1992a) The pivotal role of tumor necrosis factor $\alpha$ in the development of inflammatory hyperalgesia. Br J Pharma col 107:660-664.

Cunha FQ, Poole S, Lorenzetti BB, Veiga FH, and Ferreira SH (1999) Cytokinemediated inflammatory hyperalgesia limited by interleukin-4. Br J Pharmacol 126:45-50.

Czlonkowski A, Stein C, and Herz A (1993) Peripheral mechanisms of opioid antino- 
ciception in inflammation: involvement of cytokines. Eur $J$ Pharmacol 242:229 235

De Waal Malefyt R, Abrams J, Bennet B, Figdor C, and Devries JE (1991) Interleukin-10 (IL-10) inhibits cytokine synthesis by human monocytes: an autoregulatory role of IL-10 produced by monocytes. J Exp Med 174:1209-1220.

De Waal Malefyt R, Abrams JS, Zurawski SM, Lecron JC, Mohan-Peterson S, Sanjanwala B, Bennett B, Silver J, de Vries JE, and Yssel H (1995) Differential regulation of IL-13 and IL-4 production by human CD8+ and CD4+ Th0, Th1 and Th2 T cell clones and EBV-transformed B cells. Int Immunol Sep 7:1405-1416.

Di Santo E, Adami M, Bertorelli R, and Ghezzi P (1997) Systemic interleukin-10 administration inhibits brain tumor necrosis factor production in mice. Eur $J$ Pharmacol 336:197-202.

Dinarello CA, Cannon JG, Wolff SM, Bernheim HA, Beutler B, Cerami A, Figari IS Palladino MA, and O'Connor JV Jr (1986) Tumor necrosis factor (cachectin) is an endogenous pyrogen and induces production of interleukin 1. $J$ Exp Med 163: $1443-1449$

Duarte ID, Nakamura M, and Ferreira SH (1988) Participation of the sympathetic system in acetic acid-induced writhing in mice. Braz J Med Biol Res 21:341-345

Eddy NB and Leimbach D (1953) Synthetic analgesics II. Dithienyl-butenoyl and dithenylbutyllamines. J Pharmacol Exp Ther 107:385-389.

Faccioli LH, Souza GE, Cunha FQ, Poole S, and Ferreira SH (1990) Recombinant interleukin-1 and tumor necrosis factor induce neutrophil migration "in vivo" by indirect mechanisms. Agents Actions 30:334-339.

Ferreira SH, Lorenzetti BB, Bristow AF, and Poole S (1988) Interleukin-1 $\beta$ as a potent hyperalgesic agent antagonized by a tripeptide analogue. Nature (Lond) 334:698-700.

Ferreira SH, Lorenzetti BB, and Poole S (1993) Bradykinin initiates cytokinemediated inflammatory hyperalgesia. Br J Pharmacol 110:1227-1231.

Fiorentino DF, Bond MW, and Mosmann TR (1989) Two types of mouse T helper cell. IV. Th2 clones secrete a factor that inhibits cytokine production by Th1 clones. $J$ Exp Med 170:2081-2095.

Fiorentino DF, Zlotnik A, Mosmann TR, Howard M, and O'Garra A (1991) IL-10 inhibits cytokine production by activated macrophages. J Immunol 147:38153822

Hart PH, Vitti GF, Burgess DR, Whitti GA, Piccoli DS, and Hamilton JA (1989) Potential anti-inflammatory effects of interleukin-4: suppression of human monocyte tumor necrosis factor $\alpha$, interleukin-1 and prostaglandin $\mathrm{E}_{2}$. Proc Natl Acad Sci USA 86:3803-3807.

Howard M and O'Garra A (1992) Biological properties of IL-10. Immunology Today 13:198-200

Isomaki P, Luukkainen R, Toivanen P, and Punnonen J (1996) The presence of Interleukin-13 in rheumatoid synovium and its anti-inflammatory effects on synovial fluid macrophages from patients with rheumatoid arthritis. Arthritis Rheum 39:1693-1702.

Lorenzetti BB, Poole S, Veiga FH, Cunha FQ, and Ferreira SH (2001) Cytokinemediated inflammatory hyperalgesia limited by interleukin-13. Eur Cytokine Netw 12:260-267.

McKenzie AN, Culpepper JA, de Waal Malefyt R, Briere F, Punnonen J, Aversa G, Sato A, Dang W, Cocks G, Menon S, et al. (1993) Interleukin-13, a T cell derived cytokine that regulates human monocyte and B cell function. Proc Natl Acad Sc USA 90:3735-3739.

Muchamuel T, Menon S, Pisacane P, Howard MC, and Cockayne DA (1997) IL-13 protects mice from lipopolysaccharide-induced lethal endotoxemia: correlation with down-modulation of TNF- $\alpha$, IFN- $\gamma$ and IL-2 production. $J$ Immunol 158: $2898-2903$.

Nakamura M and Ferreira SH (1987) A peripheral sympathetic component in inflammatory hyperalgesia. Eur J Pharmacol 135:145-153.

Niiro H, Otsuka T, Izuhara K, Yamaoka K, Ohshima K, Tanabe T, Hara S, Nemoto Y, Tanaka Y, Nakashima H, and Niho Y (1997) Regulation by interleukin-10 and interleukin-4 of cyclooxygenase-2 expression in human neutrophils. Blood 89: 1621-1628.

Niiro H, Otsuka T, Tanabe T, Hara S, Kuga S, Nemoto Y, Tanaka Y, Nakashima H, Kitajima S, Abe M, et al. (1995) Inhibition by interleukin-10 of inducible cyclooxygenase expression in lipopolysaccharide-stimulated monocytes: its underlying mechanism in comparison with IL-4. Blood 85:3736-3745.

Onoe Y, Miyaura C, Kaminakayashiki T, Nagai Y, Noguchi K, Chen QR, Seo H, Ohta H, Nozawa S, Kudo I, and Suda T (1996) IL-13 and IL-4 inhibit bone resorption by suppressing cyclooxygenase-2-dependent prostaglandin synthesis in osteoblasts. $J$ Immunol 156:758-764.

Oswald IP, Wynn TA, and Sher A (1992) Interleukin 10 inhibits macrophage microbicidal activity by blocking the endogenous production of tumor necrosis factor- $\alpha$ required as a costimulatory factor for interferon gamma-induced activation. Proc Natl Acad Sci USA 89:8676-8680.

Plunkett JA, Yu CG, Easton JM, Bethea JR, and Yezierski RP (2001) Effects of interleukin-10 (IL-10) on pain behavior and gene expression following excitotoxic spinal cord injury in the rat. Exp Neurol Mar 168:144-154.

Poole S, Cunha FQ, Selkirk S, Lorenzetti BB, and Ferreira SH (1995) Cytokinemediated inflammatory hyperalgesia limited by interleukin-10. $\mathrm{Br} J$ Pharmacol 115:684-688.

Ribeiro RA, Vale ML, Thomazzi SM, Cunha FQ, and Ferreira SH (2000) Involvement of resident macrophages and mast cells in the writhing nociceptive response induced by zymosan and acetic acid in mice. Eur J Pharmacol 387:111-118.

Rocha FA, Aragao AG Jr, Oliveira RC, Pompeu MM, Vale MR, and Ribeiro RA (1999 Periarthritis promotes gait disturbance in zymosan-induced arthritis in rats. Inflamm Res 48:485-490.

Röcken M, Racke M, and Shevach EM (1996) IL-4-induced immune deviation as antigen-specific therapy for inflammatory autoimmune disease. Immunol Today 17:225-231.

Seitz M, Loetscher P, Dewald B, Towbin H, Ceska M, and Baggiolini M (1994) Production of interleukin-1 receptor antagonist, inflammatory chemotactic proteins and prostaglandin $\mathrm{E}$ by rheumatoid and osteoarthritic synoviocytes: regulation by IFN- $\gamma$ and IL-4. J Immunol 152:2060-2065.

Thomazzi SM, Ribeiro RA, Campos DI, Cunha FQ, and Ferreira SH (1997) Tumor necrosis factor, interleukin-1 and interleukin- 8 mediate the nociceptive activity of the supernatant of LPS-stimulated macrophages. Mediators of Inflammation 6:195-200.

Tonussi CR and Ferreira SH (1992) Rat-knee joint incapacitation test: an objective screen for central and peripheral analgesics. Pain 48:421-427.

Address correspondence to: Ronaldo Albuquerque Ribeiro, Departamento de Fisiologia e Farmacologia, Faculdade de Medicina, Universidade Federal do Ceará, R. Cel. Nunes de Melo 1127, 60.430-270 Fortaleza CE, Brazil. E-mail: ribeiror@ufc.br 